\title{
New constraints on the gas age-ice age difference along the EPICA ice cores, 0-50 kyr
}

\author{
L. Loulergue ${ }^{1}$, F. Parrenin ${ }^{1}$, T. Blunier ${ }^{2}$, J.-M. Barnola ${ }^{1}$, R. Spahni ${ }^{2}$, A. Schilt ${ }^{2}$, G. Raisbeck ${ }^{3}$, and J. Chappellaz ${ }^{1}$ \\ ${ }^{1}$ Laboratoire de Glaciologie et de Géophysique de l'Environnement (LGGE), CNRS, Université Joseph Fourier - Grenoble, \\ BP96 38402 Saint Martin d'Heres Cedex, France \\ ${ }^{2}$ Climate and Environmental Physics, Physics Institute, University of Bern, Sidlerstrasse 5, 3012 Bern, Switzerland \\ ${ }^{3}$ Centre de Spectrométrie Nucléaire et de Spectrométrie de Masse (CSNSM), IN2P3-CNRS-Université de Paris-Sud, Bat 108, \\ 91405 Orsay Cedex, France
}

Received: 14 February 2007 - Published in Clim. Past Discuss.: 5 March 2007

Revised: 25 July 2007 - Accepted: 15 August 2007 - Published: 28 August 2007

\begin{abstract}
Gas is trapped in polar ice sheets at $\sim 50-120 \mathrm{~m}$ below the surface and is therefore younger than the surrounding ice. Firn densification models are used to evaluate this ice age-gas age difference ( $\Delta$ age) in the past. However, such models need to be validated by data, in particular for periods colder than present day on the East Antarctic plateau. Here we bring new constraints to test a firn densification model applied to the EPICA Dome C (EDC) site for the last $50 \mathrm{kyr}$, by linking the EDC ice core to the EPICA Dronning Maud Land (EDML) ice core, both in the ice phase (using volcanic horizons) and in the gas phase (using rapid methane variations). We also use the structured ${ }^{10} \mathrm{Be}$ peak, occurring $41 \mathrm{kyr}$ before present (BP) and due to the low geomagnetic field associated with the Laschamp event, to experimentally estimate the $\Delta$ age during this event. Our results seem to reveal an overestimate of the $\Delta$ age by the firn densification model during the last glacial period at EDC. Tests with different accumulation rates and temperature scenarios do not entirely resolve this discrepancy. Although the exact reasons for the $\Delta$ age overestimate at the two EPICA sites remain unknown at this stage, we conclude that current densification model simulations have deficits under glacial climatic conditions. Whatever the cause of the $\Delta$ age overestimate, our finding suggests that the phase relationship between $\mathrm{CO}_{2}$ and EDC temperature previously inferred for the start of the last deglaciation (lag of $\mathrm{CO}_{2}$ by $800 \pm 600 \mathrm{yr}$ ) seems to be overestimated.
\end{abstract}

Correspondence to: L. Loulergue

(loulergue@lgge.obs.ujf-grenoble.fr)

\section{Introduction}

Gas records in ice cores allow one to reconstruct changes in the atmospheric composition (e.g. Siegenthaler et al., 2005; Spahni et al., 2005; Flückiger et al., 2002). They also allow to compare between Greenland and Antarctic ice records, when used as correlative tools (Bender et al., 1994; Blunier et al., 1997, 1998; Blunier and Brook, 2001; Steig et al., 2002; Landais et al., 2004). Lastly, their phase relationship with ice records provides a constraint on the mechanisms responsible for atmospheric composition changes (e.g. Monnin et al., 2001). The second and third application of gas records critically depends on uncertainties in the difference between the age of the gas and the age of the surrounding ice matrix ( $\triangle$ age) (Schwander et al., 1997).

Different methods are used to determine the ice/gas difference (as a function of age at the same depth - hereafter $\Delta$ age, or as a function of depth at the same age - hereafter $\Delta$ depth) in ice cores: using a firn densification model which simulates gas trapping as a function of firn physical properties and climatic conditions (e.g. Arnaud et al., 2000), comparing a temperature signal recorded both in the ice matrix and in the gas phase (e.g. Severinghaus et al., 1998; Caillon et al., 2001), or taking $\delta^{15} \mathrm{~N}$ of $\mathrm{N}_{2}$ as a proxy for the Lock-In Depth (LID) where gas diffusion ceases (e.g. Goujon et al., 2003; Sowers et al., 1992). The firn densification model requires specific inputs to compute firn density and thus gas trapping, such as the ice chronology and past variations of surface temperature and accumulation rate at the site of deposition. The most recent versions of these models include heat diffusion in firn and its effect on firn sintering. They are tested against present-day density and temperature profiles measured at different sites of Antarctica and

Published by Copernicus Publications on behalf of the European Geosciences Union. 
Greenland. For the past, usually no present-day analogue exists in terms of temperature and accumulation conditions. Therefore the model output can only be tested against other methods to determine $\Delta$ age, when available. This is the case in Greenland where $\Delta$ age can also be determined accurately in the past, thanks to the abrupt Greenland surface warming and cooling inducing a temperature gradient in the firn column. This temperature gradient causes isotopically heavier molecules to migrate towards the cold end (Severinghaus et al., 1998). As the isotopic ratios of atmospheric nitrogen and argon are constant at millennial time scale in the atmosphere, their anomalies set the starting point of surface temperature changes in the gas record. With the temperature variation being recorded both in the ice and gas isotopic compositions, $\Delta$ depth is obtained. With an underlying timescale it can be transferred into a $\Delta$ age. Unfortunately, in Antarctica, thermal diffusion produces isotope anomalies usually too small to be detected. In addition, the lower accumulation rate compared to Greenland results in larger $\Delta$ age accompanied by more uncertain $\Delta$ age calculations.

The uncertainty of $\Delta$ age estimates in Antarctica is critical regarding the question of leads and lags between temperature and greenhouse gases variations in the past, which constrain the mechanisms responsible for these changes. At the onset of the last deglaciation (Termination I), based on a firn densification model Monnin et al. (2001) found a lag of $800 \pm 600 \mathrm{yr}$ of $\mathrm{CO}_{2}$ versus EDC temperature. Using the Siple Dome ice core and a firn densification model, Ahn et al. (2004) inferred a smaller lag of 210 to $330 \mathrm{yr}$. With the Byrd ice core, Neftel et al. (1988) also inferred a lag of $700 \pm 500$ yr. Fischer et al. (1999) suggested an average lag of $\mathrm{CO}_{2}$ over Vostok surface temperature of $600 \pm 400 \mathrm{yr}$ over the last three Terminations, again using a firn densification model. Lastly, using trends in the ${ }^{36} \mathrm{Ar} /{ }^{40} \mathrm{Ar}$ isotopic ratio during Termination III, a lag of $\mathrm{CO}_{2}$ on the Vostok warming during the entire deglaciation was found, with a value of $800 \pm 200 \mathrm{yr}$ (Caillon et al., 2003). Better estimates of the $\Delta$ age are clearly required to ascertain these estimated lags. Some of them result from densification models runs under conditions without present-day analogues.

One way to improve the accuracy of $\Delta$ age estimates in Antarctica is to rely on stratigraphic markers recorded both in the ice matrix and in the trapped gas in two ice cores. This allows the correlation of the ice records in addition to the gas correlation, and thus an evaluation of $\Delta$ age as a function of time. The ${ }^{10} \mathrm{Be}$ anomaly (Raisbeck et al., 2002) provides such a marker in the ice. It is observed as a highly structured peak believed to be due to a low geomagnetic field associated with the Laschamp Event (Mazaud et al., 1994), centered at $40.4 \pm 2 \mathrm{kyr}$ BP (Guillou et al., 2004). Yiou et al. (1997) and Raisbeck et al. (2002) showed that this ${ }^{10} \mathrm{Be}$ peak is contemporary with the Dansgaard-Oeschger event (DO) \#10.

Here we present new $\mathrm{CH}_{4}$ data obtained on the EDC ice core $\left(75^{\circ \prime} \mathrm{S}, 123^{\circ} \mathrm{E}, 3233 \mathrm{~m}\right.$ a.s.l., $\left.25 \mathrm{~kg} \mathrm{~m}^{-2} \mathrm{yr}^{-1}\right)$ over the last $55 \mathrm{kyr}$ BP (before AD 1950), that complement recently published $\mathrm{CH}_{4}$ data along the EPICA Dronning Maud Land (EDML) ice core $\left(75^{\circ} \mathrm{S}, 0^{\circ} \mathrm{E}, 2892 \mathrm{~m}\right.$ a.s.1., $64 \mathrm{~kg} \mathrm{~m}^{-2} \mathrm{yr}^{-1}$ ) (EPICA Community Members, 2006) and a stack of Greenland $\mathrm{CH}_{4}$ records (Blunier et al., 2007). We then evaluate different accumulation and temperature scenarios against the objective that the $\triangle$ age at EDC and EDML obtained by the densification model should produce 1) two consistent gas age scales at EDC and EDML; and 2) a North-South synchronisation compatible with the one obtained from the ${ }^{10} \mathrm{Be}$ peak during the Laschamp event.

\section{Data and models used}

\section{$2.1 \quad$ Ice chronologies}

When evaluating $\Delta$ age and $\Delta$ depth with a firn densification model, a chronology for the ice has to be imposed.

For the NorthGRIP core, we use the GICC05 chronology obtained by annual layer counting from 0 to $42 \mathrm{kyr}$ BP (Andersen et al., 2006; Rasmussen et al., 2006; Svensson et al., 2006; Vinther et al., 2006). The GICC05 age at the location of the ${ }^{10} \mathrm{Be}$ peak is $41.2 \pm 1.6 \mathrm{kyr} \mathrm{BP}$, and matches recent independent estimates within a few centuries (Svensson et al., 2006). Note that the uncertainty on the time spent between two nearby depth levels is smaller than the error on the absolute ages, the latter being cumulative with depth.

The new EDC ice chronology (hereafter referred to as EDC3, Parrenin et al., 2007a) is based on a relatively simple ice flow model applicable to ice domes. Several control age windows are used (from absolutely dated horizons and from comparison with other paleoclimate records) to constrain the free parameters of the model via an inverse method (Parrenin et al., 2001). For the last $50 \mathrm{kyr}$, EDC3 is matched onto GICC05 (Parrenin et al., 2007a) at several tie points: during the last $6 \mathrm{kyr}$ (by ${ }^{10} \mathrm{Be}-{ }^{10} \mathrm{Be}$ synchronization), during the last deglaciation (by methane-isotope synchronization) and during the Laschamp event (by ${ }^{10} \mathrm{Be}-{ }^{10} \mathrm{Be}$ synchronization).

The corresponding chronology for EDML (hereafter EDML1, Ruth et al., 2007) has been derived by synchronizing the EDML and EDC ice cores using volcanic horizons and dust peaks. The tie points are based on continuous sulphate, electrolytic conductivity, dielectric profiling, particulate dust and $\mathrm{Ca}^{2+}$ data available for both cores (Severi et al., 2007). Due to common changes in the Patagonian dust source strength and the hemispheric significance of major volcanic eruptions, this procedure is justified. For the last $75 \mathrm{kyr}$ (the period of interest in this study), the synchronization is mainly based on unambiguous volcanic markers recorded in the sulphate parameter, providing a synchronization to better than \pm 100 years (on average \pm 35 years, Ruth et al., 2007). 


\subsection{Temperature and accumulation rate parameterizations}

$\triangle$ age estimates from a firn densification model (Pimienta et al., 1987; Arnaud et al., 2000; Goujon et al., 2003) require knowing the history of surface temperature and accumulation rate at the site of deposition. Below we present the temperature and accumulation rate parameterizations that will be used further on.

Accumulation rate $A$ and temperature $T$ are deduced from the deuterium content of the ice $\delta \mathrm{D}$, through the following relationships:

$T=T^{0}+\alpha \Delta \delta D_{\text {cor }}$

$A=A^{0} \exp \left(\beta \Delta \delta D_{\text {smo }}\right)$

where $A^{0}$ and $T^{0}$ are surface accumulation rate and temperature for the present. $\Delta \delta \mathrm{D}_{\text {corr }}$ corresponds to the presentday value $\delta \mathrm{D}_{0}$ isotope corrected for the variations in temperature and isotope at the source of the air masses (Parrenin et al., 2007). The latter is determined through isotopic reconstructions of benthic foraminifera (Bintanja et al., 2005). $\Delta \delta D_{\text {smo }}$ is a $50-\mathrm{yr}$ running average of $\Delta \delta D_{\text {corr }}$ (to remove the noise of water isotopic ratios unrelated with accumulation rate changes). $\alpha$ represents the spatial slope of the present-day isotopic thermometer and $\beta$ represents the glacial-interglacial amplitude of the accumulation rate change. The $\beta$ value is estimated at 0.0157 for EDC (Parrenin et al., 2007) and 0.045 for EDML (EPICA Community Members, 2006). This correction factor will be described and used later on in the manuscript.

At EDML, only $\delta^{18} \mathrm{O}$ of ice was measured and a synthetic $\delta \mathrm{D}$ record is obtained following:

$\delta D=8 \cdot \delta^{18} \mathrm{O}+10$

The present-day isotopic content, temperature and accumulation rates are respectively $\delta \mathrm{D}_{0}=-396.5 \%, T^{0}=217.5 \mathrm{~K}$, $A^{0}=2.84 \mathrm{~cm}-\mathrm{IE} / \mathrm{yr}$ (cm ice equivalent per year) for EDC (Parrenin et al., 2007) and $\delta D_{0}=-351.22 \%$ o, $T^{0}=228.65 \mathrm{~K}$, $A^{0}=6.4 \mathrm{~cm}-\mathrm{IE} / \mathrm{yr}$ for EDML (EPICA, Community Members, 2006).

Furthermore, a positive correction was applied to the EDC accumulation rate during the early Holocene, in order to match EDC3 onto GICC05 during the last deglaciation (see Parrenin et al., 2007, for more details).

The average glacial accumulation rate at EDML drill site calculated with Eq. (2) is about $2.9 \mathrm{~cm}-\mathrm{IE} /$ year (EPICA Community Members, 2006), a value not far from the present one for Dome C (2.84 cm-IE/year) (Parrenin et al., 2007).

\subsection{Methane records}

We use $\mathrm{CH}_{4}$ records from EDC and EDML back to $55 \mathrm{kyr} \mathrm{BP}$ (Fig. 1) (EPICA Community Members, 2006). For EDC, the resolution of the existing methane data (Spahni et al., 2005;

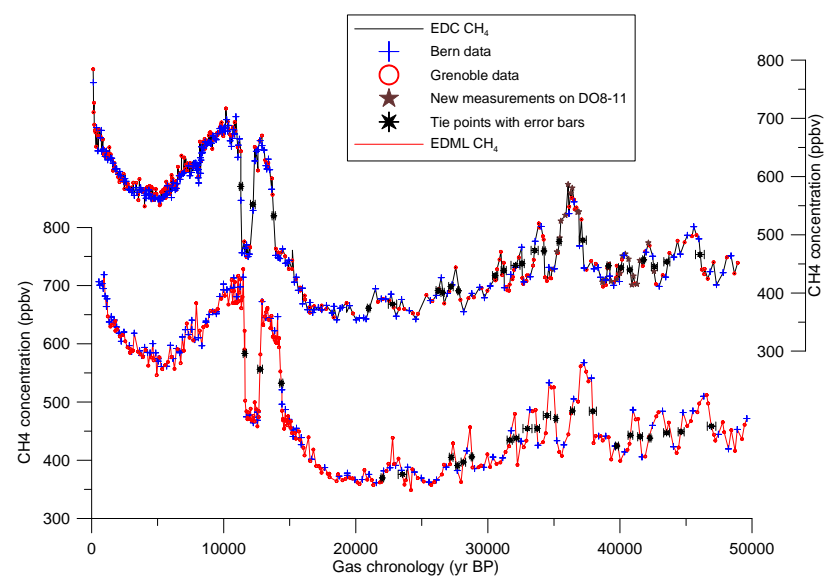

Fig. 1. Methane concentrations at EDML (red line, bottom) and EDC (black line, top) during the last $55 \mathrm{kyr}$ BP. The EDC methane record consists of results published by Spahni et al. (2005), Flückiger et al. (2002), Monnin et al. (2001) (Bern data, blue cross), new data doubling the time resolution (LGGE data, red dots) and additional new data specifically improving the time resolution between the DO \#8 and \#11 events (LGGE data, brown stars). The EDML methane data, already published in EPICA Community Members (2006), have been measured at LGGE and Bern.

Black stars and their error bars correspond to the $\mathrm{CH}_{4}$ tie points. Gas ages have been computed with the Goujon/Arnaud model (Goujon et al., 2003) according to scenario 1.

Flückiger et al., 2002) has been doubled (leading to an average temporal resolution of 93 years, and up to 40 years for the Holocene) and extra samples were analyzed around DO 8 to 11 corresponding to the location of the ${ }^{10} \mathrm{Be}$ peak (resolution of about $108 \mathrm{yr}$, see Supplement_1 at http://www.clim-past. net/3/527/2007/cp-3-527-2007-supplement.zip). The measurements were performed at Bern and Grenoble with a wet extraction technique. Details of the method can be found in Chappellaz et al. (1997). For consistency with previously published EDC and EDML $\mathrm{CH}_{4}$ data sets, the $\mathrm{CH}_{4}$ mixing ratios obtained at LGGE are increased by $6 \mathrm{ppbv}$ to be in accordance with the Bern values (Spahni et al., 2005). The measurement uncertainty is $\pm 10 \mathrm{ppbv}$ (Chappellaz et al., 1997). Numerical values are available from the NOAA World Data Center for Paleoclimatology (http: //www.ncdc.noaa.gov/paleo/data.html).

2.4 The $41 \mathrm{kyr}{ }^{10} \mathrm{Be}$ peak in Greenland and Antarctic ice cores

${ }^{10} \mathrm{Be}$ has been measured in detail on the EDC (Raisbeck et al., 2002; Raisbeck et al., 2007) and GRIP (Yiou et al., 1997) ice cores, depicting the full structure of the peak at $41 \mathrm{kyr}$ BP. Two sub-peaks can be clearly identified in this structure and serve as synchronization markers between both cores. The position uncertainty of the two sub-peaks during the Laschamp event is about $\pm 1.1 \mathrm{~m}$ (Raisbeck et al., 
Table 1. $\Delta$ age and $\triangle$ depth estimates at EDC and EDML at the location of the ${ }^{10} \mathrm{Be}$ sub-peaks.

Definitions of depths $d_{1}$ and $d_{2}$, and ages $a_{1}$ and $a_{2}$ at NorthGRIP are given in the legend of Fig. 2. For EDML- $d_{1}$, the error bar represents the uncertainty of the ${ }^{10} \mathrm{Be}$ position in EDC, plus that in the EDC-EDML synchronisation. Ages $a_{1}$ and $a_{2}$ are on the GICC05 chronology, and the error bar on $a_{2}$ is estimated as the uncertainties on the synchronisation with EDC and EDML.

\begin{tabular}{rlrllllllll}
\hline & & $\begin{array}{l}\text { (EDC or } \\
\text { EDML)- } d_{1}\end{array}$ & $\begin{array}{l}\text { (EDC or } \\
\text { EDML)- } d_{2}\end{array}$ & $\begin{array}{l}\text { GRIP- } d_{1} \\
(\mathrm{~m})\end{array}$ & $\begin{array}{l}\text { NGRIP- } d_{1} \\
(\mathrm{~m})\end{array}$ & $\begin{array}{l}\text { NGRIP- } d_{2} \\
(\mathrm{~m})\end{array}$ & $a_{1}(\mathrm{yr}$ BP) & $a_{2}(\mathrm{yr}$ BP) & $\Delta$ age $(\mathrm{yr})$ & $\Delta$ depth $(\mathrm{m})$ \\
\hline & Peak 1 & $735.5 \pm 1.1$ & $782.8 \pm 2$ & $2231.9 \pm 1.1$ & $2110.1 \pm 1.1$ & 2032.2 & 40820 & $36860 \pm 150$ & $3960 \pm 290$ & $47.3 \pm 2.3$ \\
EDC & Peak 2 & $744.8 \pm 1.1$ & $792.3 \pm 2$ & $2246.2 \pm 1.1$ & $2127.5 \pm 1.1$ & 2052.6 & 41700 & $37660 \pm 150$ & $4040 \pm 290$ & $47.5 \pm 2.3$ \\
\hline & Peak 1 & $1368.4 \pm 2.2$ & $1389.8 \pm 4$ & $2231.9 \pm 1.1$ & $2110.1 \pm 1.1$ & 2092.2 & 40820 & $39740 \pm 150$ & $1080 \pm 240$ & $21.4 \pm 4.6$ \\
EDML & Peak 2 & $1383.3 \pm 2.4$ & $1406.4 \pm 4$ & $2246.2 \pm 1.1$ & $2127.5 \pm 1.1$ & 2104.5 & 41700 & $40480 \pm 150$ & $1220 \pm 220$ & $23.1 \pm 4.6$ \\
\hline
\end{tabular}

2007). The ${ }^{10} \mathrm{Be}$ record at NorthGRIP is not completed yet. Therefore the position of the ${ }^{10} \mathrm{Be}$ sub-peaks at NorthGRIP is based on a GRIP-NorthGRIP volcanic synchronization (Rasmussen et al., 2007). The uncertainty associated with this GRIP-NorthGRIP synchronization is small and neglected here.

Measurements of the ${ }^{10} \mathrm{Be}$ peak are not yet available for the EDML ice core. Here we use the EDC-EDML volcanic synchronization (Severi et al., 2007) to determine its probable location in the core. The estimated depths of the two ${ }^{10} \mathrm{Be}$ sub-peaks in the EDML core are shown in Table 1. The uncertainty on this synchronisation is small and estimated to be respectively $\pm 0.23 \mathrm{~m}$ and $\pm 0.35 \mathrm{~m}$ at EDML (Ruth et al., 2007).

\subsection{Firn densification modelling}

In order to determine $\Delta$ age and $\Delta$ depth, different firn densification models have been developed previously. The first empirical steady state firn densification model based on ice deformation studies was developed by Herron and Langway (1980). This model was then improved by Pimienta (1987) (hereafter referred to as Pimienta-Barnola model) who explicitely took into account the pressure in the physical formulation. This model was applied for past climatic conditions at Vostok by Barnola et al. (1991). Schwander et al. (1997) further incorporated the heat transfer in a similar model. Heat transfer consists of diffusion and advection of temperature in the firn, and leads under present day conditions to an average temperature at the close-off depth slightly warmer than at the surface. Note that the same model is used in Blunier et al. (2007). Arnaud et al. (2000) then developed a more advanced densification model which considers two densification stages: pure sliding of snow grains for density lower than $\sim 0.55 \mathrm{~g} / \mathrm{cm}^{3}$, and pure deformation of grains for density higher than $\sim 0.55 \mathrm{~g} / \mathrm{m}^{3}$. Goujon et al. (2003) then incorporated the heat transfer into this model. Very recently, Salamatin et al. (2007) proposed a model similar to the Arnaud model but considers both densification processes (sliding and deformation) simultaneously from the surface down to the close-off depth. Here we use the Goujon/Arnaud firn densification model (Goujon et al., 2003).

\section{Empirical constraints on EDC and EDML $\triangle$ ages}

Two types of empirical constraints on the EDC and EDML $\Delta$ ages are used. The first is based on EDC-EDML ice (sulphate) and gas (methane) synchronization during the last glacial period (Sect. 3.1). The second involves their synchronisation to NorthGRIP during the Laschamp event (Sect. 3.2).

\subsection{EDC-EDML $\mathrm{CH}_{4}$ synchronisation}

As the ice of the two EPICA ice cores is well synchronized via volcanic horizons ( \pm 35 years, Severi et al., 2007; Ruth et al., 2007), a correct estimate of $\Delta$ age/ $\Delta$ depth at both sites should lead to synchronised $\mathrm{CH}_{4}$ records in the gas phase. We use the sharp methane transitions to define match points between the two cores, taken at middle slope of each $\mathrm{CH}_{4}$ sharp increase and decrease (Table 2). The comparison of the EDML and EDC gas ages for these events allows evaluation of the accuracy of the two modelled $\Delta$ ages and $\Delta$ depths.

Note that contrary to the information inferred by comparison to NorthGRIP during the Laschamp event (see next section), this constraint is only relative. Namely, it cannot provide independent validation on the absolute numbers of $\Delta$ age, because systematic errors in both cores could lead to an incidental agreement of their gas timescales. The accumulation rate being more than twice as large at EDML than at EDC, its $\triangle$ age is smaller and better constrained. Consequently, the EDML-EDC methane synchronization brings more constraints on the EDC $\triangle$ age.

In the following, this empirical constraint will be referred to as the EDC-EDML constraint.

3.2 $\Delta$ age and $\Delta$ depth constraints during the Laschamp event

$\Delta$ age and $\Delta$ depth at the depth of the ${ }^{10} \mathrm{Be}$ peak in the two EPICA cores is estimated by linking both their ice 
Table 2. Depth of the methane tie points for the EDML-EDC gas synchronisation. Tie points are located at the middle of each sharp transition. The specified uncertainty $(2 \sigma)$ on the match has been determined as a function of depth, and then translated to ages using the EDC3 and EDML1 chronologies.

\begin{tabular}{|c|c|c|c|c|c|}
\hline Events & EDML depth (m) & $\mathrm{CH} 4$ (ppbv) & EDC depth $(m)$ & $\mathrm{CH} 4$ (ppbv) & $\begin{array}{l}\text { Uncertainties on } \\
\text { the } \\
\text { synchronisation } \\
\text { EDML-EDC (yrs) }\end{array}$ \\
\hline$\overline{\text { 1st transition (PB_YD) }}$ & 717.6 & 583.6 & 418.2 & 583.0 & 124.6 \\
\hline 2nd transiton (YD_BO) & 766.4 & 556.3 & 442.7 & 552.2 & 172.7 \\
\hline 3th transition (BO_LGM) & 830.2 & 532.3 & 476.1 & 532.6 & 122.3 \\
\hline DO2 end & 1032.9 & 369.7 & 579.9 & 373.9 & 98.4 \\
\hline DO2 onset & 1072.9 & 375.7 & 599.9 & 380.9 & 321.3 \\
\hline DO3 end & 1148.0 & 405.0 & 635.4 & 404.0 & 141.1 \\
\hline DO3 onset & 1155.1 & 390.9 & 639.1 & 401.0 & 127.3 \\
\hline DO4 end & 1162.7 & 396.7 & 645.9 & 411.0 & 170.1 \\
\hline DO4 onset & 1174.2 & 405.7 & 651.9 & 403.7 & 56.7 \\
\hline DO5 end & 1224.0 & 434.5 & 681.6 & 429.8 & 196.7 \\
\hline DO5 onset & 1233.7 & 437.7 & 688.1 & 438.4 & 199.7 \\
\hline DO6 end & 1248.6 & 454.3 & 697.5 & 447.5 & 343.2 \\
\hline DO6 onset & 1261.1 & 454.5 & 702.1 & 450.7 & 170.5 \\
\hline DO7 end & 1272.9 & 476.8 & 712.5 & 473.1 & 268.0 \\
\hline DO7onset & 1286.4 & 471.7 & 719.7 & 472.2 & 98.0 \\
\hline DO8 end & 1308.5 & 484.9 & 732.0 & 488.4 & 146.4 \\
\hline DO8 onset & 1338.6 & 484.3 & 751.3 & 490.7 & 271.0 \\
\hline DO9 peak & 1374.6 & 424.5 & 774.7 & 446.7 & 117.6 \\
\hline D010 end & 1391.4 & 442.9 & 784.1 & 443.4 & 183.6 \\
\hline D010 onset & 1404.6 & 440.5 & 790.6 & 439.8 & 183.6 \\
\hline DO11 end & 1416.0 & 438.1 & 801.5 & 456.9 & 75.4 \\
\hline DO11 onset & 1435.8 & 447.1 & 810.1 & 445.2 & 223.0 \\
\hline DO12 end & 1452.9 & 448.9 & 820.4 & 453.5 & 223.0 \\
\hline D012 onset & 1491.3 & 458.5 & 848.1 & 465.9 & 330.0 \\
\hline
\end{tabular}

and gas signals to NorthGRIP. The ice link is obtained by ${ }^{10} \mathrm{Be}-{ }^{10} \mathrm{Be}$ synchronization for both ${ }^{10} \mathrm{Be}$ sub-peaks during the Laschamp event. The gas link is obtained by matching the EPICA $\mathrm{CH}_{4}$ records to the NorthGRIP isotopic record, assuming that these two records are synchronous during the rapid DO transitions (Huber et al., 2006; Flückiger et al., 2004).

\subsubsection{The $\Delta$ age method}

The method is illustrated in Figs. 2, 3a for EDC and 3b for EDML. One of the ${ }^{10} \mathrm{Be}$ sub-peaks is found at the ice depths DC- $d_{1}$ at EDC and NG- $d_{1}$ at NorthGRIP. The corresponding GICC05 age is $a_{1}$. The age of the methane at the same EDC depth DC- $d_{1}$ is younger than the age $a_{1}$ with a difference of $\Delta$ age. We synchronise this methane event with its concomitant NorthGRIP isotope event, being found shallower than the ${ }^{10} \mathrm{Be}$ sub-peak at a depth NG- $d_{2}$ and with a GICC05 age $a_{2}$. Therefore, the age difference $a_{1}-a_{2}$ is an indirect measurement of the $\Delta$ age at the EDC depth DC- $d_{1}$.
At EDC, at the depth of the ${ }^{10} \mathrm{Be}$ peak, one finds DO \#8 in the gas phase. At EDML, one finds DO \#9 due to the smaller $\Delta$ age.

The overall uncertainty of this $\Delta$ age corresponds to the square root of the sum of the squares of the uncertainties on:

1. the ${ }^{10} \mathrm{Be}$ NorthGRIP-EDC synchronisation;

2. the isotope-methane NorthGRIP-EDC synchronisation;

3. the GICC05 age difference $a_{1}-a_{2}$, that is to say the number of uncertain annual layers between the NG- $d_{1}$ and NG- $d_{2}$ depths (which is much smaller than the uncertainty on the absolute age at these depths). Consequently, the precision of our $\Delta$ age estimate is directly dependent on the precision of the GICC05 age scale.

4. the uncertainties on the linear interpolation between NorthGRIP and EDC on the ${ }^{10} \mathrm{Be}$ synchronisation

EDC $\Delta$ age with this method is found to be $3960 \pm 290 \mathrm{yr}$ and $4040 \pm 290 \mathrm{yr}$ for the two EDC ${ }^{10} \mathrm{Be}$ sub-peaks (see Table 1, 


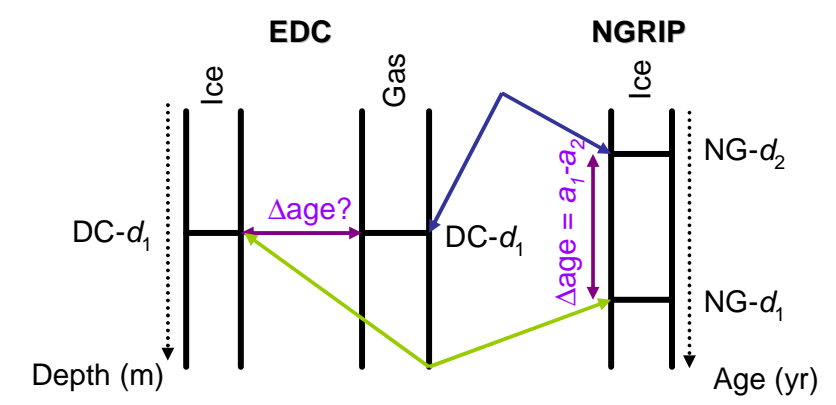

Depth (m)

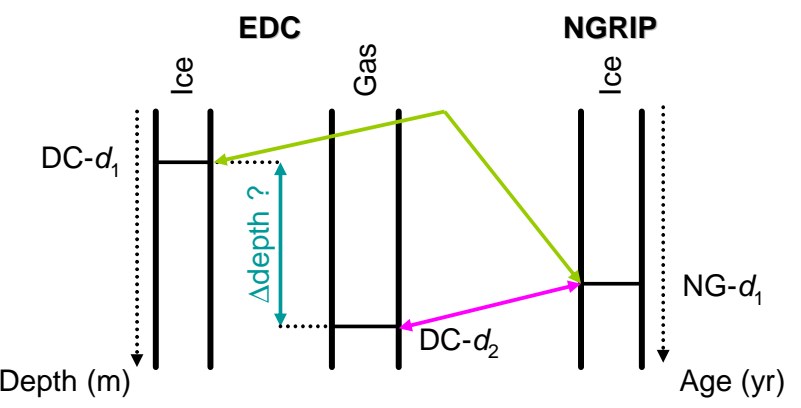

Fig. 2. Sketch of the $\Delta$ age and $\Delta$ depth determination methods for EDC (DC).

Top panel: $\Delta$ age method. The green arrow represents the ${ }^{10} \mathrm{Be}-{ }^{10} \mathrm{Be}$ tie point and the blue arrow corresponds to the methane/NorthGRIP (NG)-isotope stratigraphic link, assuming that these two records are synchronous during the rapid DO transitions (Huber et al., 2006).

Bottom panel: $\Delta$ depth method. The green arrow represents the ${ }^{10} \mathrm{Be}-{ }^{10} \mathrm{Be}$ tie point and the red arrow corresponds to the methane/NorthGRIP-isotope stratigraphic link, assuming that these two records are synchronous during the rapid DO transitions (Huber et al., 2006).

and Supplement_1 at http://www.clim-past.net/3/527/2007/ cp-3-527-2007-supplement.zip for more details).

The same procedure is applied for EDML, adding the uncertainty due to the EDML-EDC synchronization through volcanic horizons. EDML $\Delta$ age is found to be $1080 \pm 240 \mathrm{yr}$ and $1220 \pm 220 \mathrm{yr}$.

In the following, these empirical constraints will be referred to as the EDC-g $\Delta$ age and EDML- $\Delta$ age constraints, respectively.

\subsubsection{The $\Delta$ depth method}

The method is illustrated in Figs. 2 and 3. We start again by considering the EDC ice depth DC- $d_{1}$ of the ${ }^{10} \mathrm{Be}$ sub-

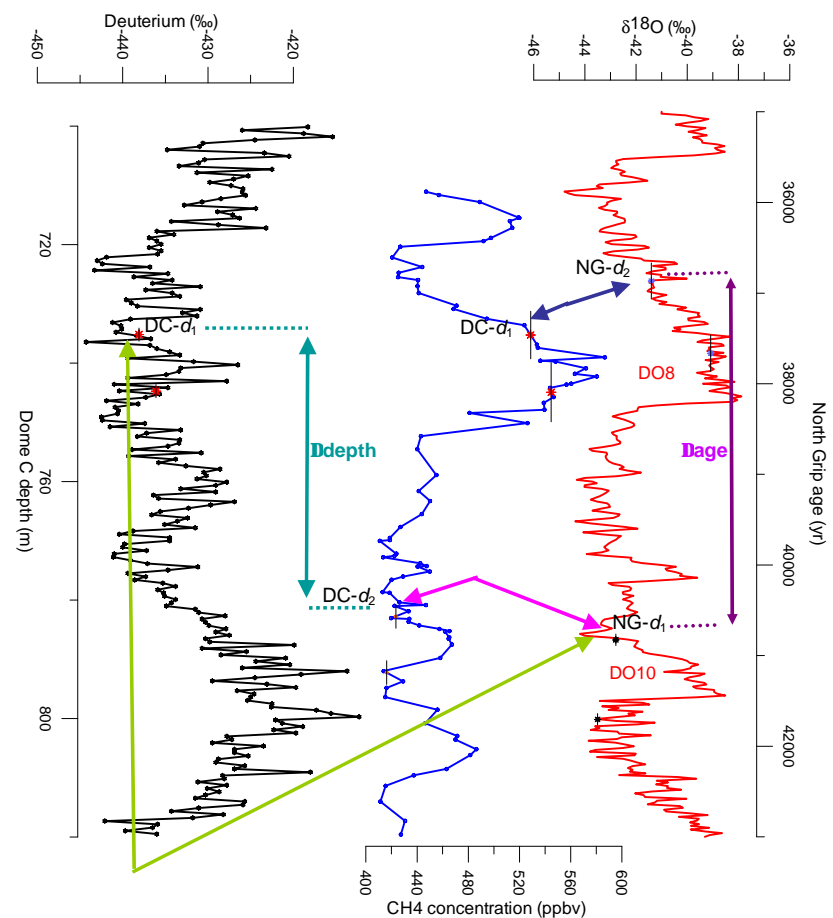

Fig. 3a. ${ }^{10} \mathrm{Be}-{ }^{10} \mathrm{Be}$ and methane/isotope stratigraphic links between EDC and NorthGRIP. The same method is applied for the second sub-peak. EDC deuterium data (Jouzel et al., 2007) are in black. EDC methane data (this study) are in blue. NorthGRIP $\delta^{18} \mathrm{O}$ (NorthGRIP community members, 2004) is in red.

peak, and the corresponding NorthGRIP ice depth NG$d_{1}$. Assuming that $\mathrm{CH}_{4}$ and the Greenland isotopes change synchronously, the methane variation corresponding to the NorthGRIP isotope variation at depth NG- $d_{1}$ is found in the EDC ice deeper than the ${ }^{10} \mathrm{Be}$ peak, at the depth DC- $d_{2}$. The gas age at DC- $d_{2}$ is identical to the ice age at DC- $d_{1}$, and the depth difference DC- $d_{2}-\mathrm{DC}-d_{1}$ is an indirect measurement of $\Delta$ depth. With this method, uncertainties in the age scales are not relevant.

The uncertainty on the $\Delta$ depth evaluation corresponds to the square root of the sum of the squares of uncertainties of the ${ }^{10} \mathrm{Be}$ NorthGRIP and EDC synchronisation, and the isotope-methane NorthGRIP-EDC synchronisation. The uncertainties introduced by the linear interpolation between NorthGRIP-EDC on the ${ }^{10} \mathrm{Be}$ synchronisation are negligible.

At EDC, $\Delta$ depth for the two ${ }^{10} \mathrm{Be}$ sub-peaks amounts to $47.3 \pm 2.3 \mathrm{~m}$ and $47.5 \pm 2.3 \mathrm{~m}$ (see Table 1 , and Supplement_1 at http://www.clim-past.net/3/527/2007/ cp-3-527-2007-supplement.zip for more details).

The same procedure is applied to EDML, adding the uncertainty on the EDML-EDC synchronisation. $\Delta$ depth then amounts to $21.4 \pm 4.6 \mathrm{~m}$ and $23.1 \pm 4.6 \mathrm{~m}$.

In the following, these empirical constraints will be referred to as the EDC- $\Delta$ depth and EDML- $\Delta$ depth constraints, respectively. 


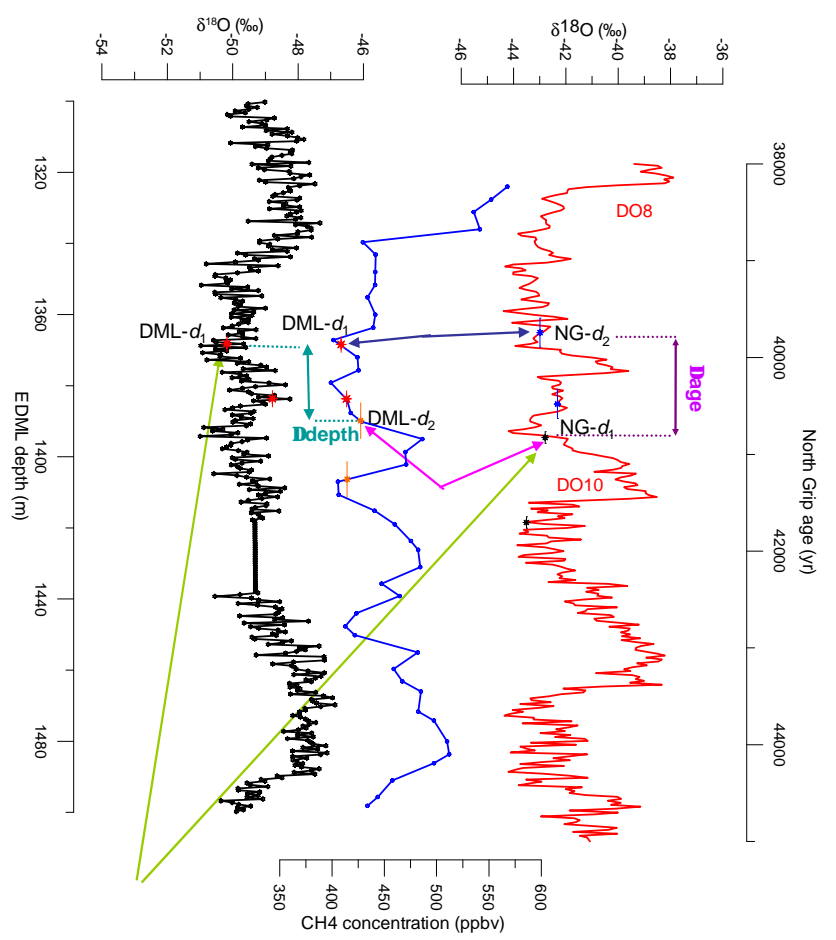

Fig. 3b. Same for EDML.

EDML deuterium data (EPICA Community Members, 2006) are in black. EDML methane data (this study) are in blue. NorthGRIP $\delta^{18} \mathrm{O}$ (NorthGRIP community members, 2004) is in red.

\section{Testing firn densification model scenarios}

In this section, we test different temperature and accumulation rate scenarios at EDC and EDML against the $\Delta$ age and $\Delta$ depth empirical constraints described in Sect. 3: EDCEDML methane synchronization, and $\Delta$ age and $\Delta$ depth at the location of the ${ }^{10} \mathrm{Be}$ peak. Numerical values are given in Supplement_2 (EDC) and 3 (EDML) (http://www.clim-past. net/3/527/2007/cp-3-527-2007-supplement.zip).

4.1 Scenario 1: EDC3 and EDML1 temperature and accumulation rate histories

With the EDC3 chronology (Parrenin et al., 2007a), the surface temperature history is deduced from the isotopic content of the ice without correction for source temperature variations. The $\beta$ coefficient in Eq. (2) has then been determined in order that the resulting chronology agrees with the absolute age of the ${ }^{10} \mathrm{Be}$ peak at $41 \mathrm{kyr} \mathrm{BP}$. The inferred value is 0.0157 . The accumulation rate has been further slightly modified in order to synchronize the EDC3 age scale onto GICC05 at several tie points (Parrenin et al., 2007a). For EDML, source temperature variations were not considered either and $\beta$ has been set to 0.015 (EPICA community members, 2006).

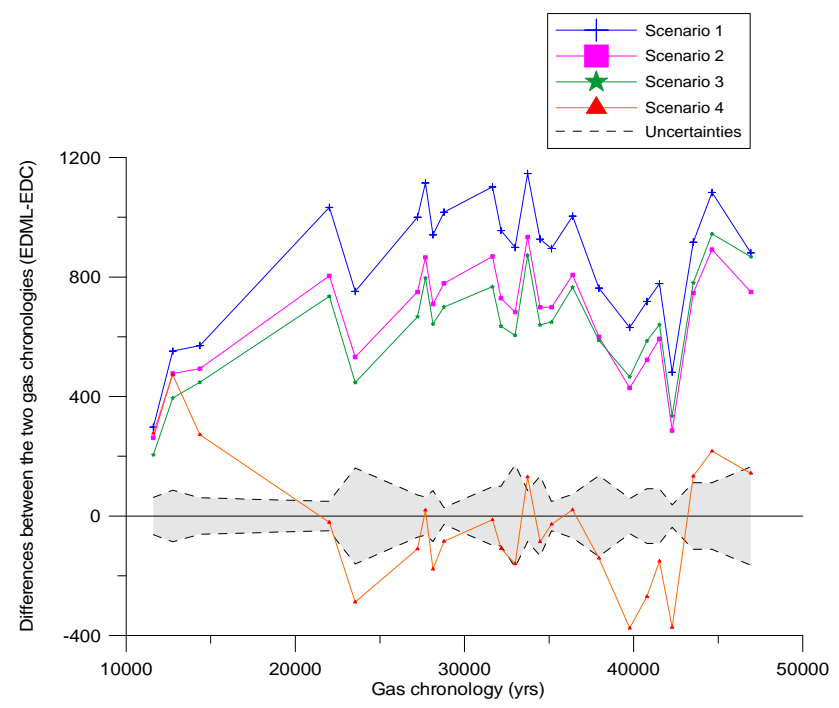

Fig. 4. Differences between the EDML and EDC gas chronologies for each methane tie point. The uncertainty (discontinuous line) on the methane synchronisation tie points is shown with the grey area. For a description of the scenarios, refer to Sect. 4.

The $\alpha$ coefficient in Eq. (1) representing the spatial slope of the present-day isotopic thermometer is estimated empirically at EDC as $0.1656 \mathrm{~K} / \%$ from the present day-surface measurements between Dumont d'Urville and Dome C (Lorius and Merlivat, 1977). For EDML, the equivalent, this time relating temperature to $\delta^{18} \mathrm{O}$, is estimated empirically as $1.220 \mathrm{~K} / \%$ from the relationship between $\delta^{18} \mathrm{O}$ and surface temperature at Dronning Maud Land (EPICA community members, 2006).

Overall, the EDC3 and EDML1 climatic inputs to the densification model provide a poor agreement with the empirical constraints (Table 3 and Fig. 4). The EDML gas time scale is always older than the EDC gas time scale (see Fig. 4), with an average difference of $850 \mathrm{yr}$. The difference ranges from $300 \mathrm{yr}$ (Younger Dryas/ Holocene transition) to $1150 \mathrm{yr}$ (onset of DO \#6). This implies that either the EDC $\triangle$ age is overestimated or the EDML one is underestimated. The discrepancy being smaller during the last deglaciation than during the last glacial period, the modelling error appears to increase during cold conditions (Fig. 4).

At the time of the two ${ }^{10} \mathrm{Be}$ sub-peaks, the EDC (EDML) modelled $\Delta$ age amounts to $5050 \mathrm{yr}$ and $5010 \mathrm{yr}$ (1370 and $1320 \mathrm{yr})$, i.e. $20(15 \%)$ larger than the empirically derived values of 3960 and $4040 \mathrm{yr}$ (1080 and $1220 \mathrm{yr}$ ) and outside their confidence interval of 290 and $290 \mathrm{yr}$ (240 and $220 \mathrm{yr}$ ). The comparison follows the same trend for the $\Delta$ depth constraints. The EDC (EDML) modelled estimates amounts to 55.3 and $55.0 \mathrm{~m}(22.9$ and $22.9 \mathrm{~m})$ and are larger by $15 \%$ (larger by about $6 \%$ ) than the empirical values. 
Table 3. Comparison between the outputs of firn densification modelling scenarios and empirical constraints as derived in Sect. 3. Cf. Sect. 4 for a description of the scenarios.

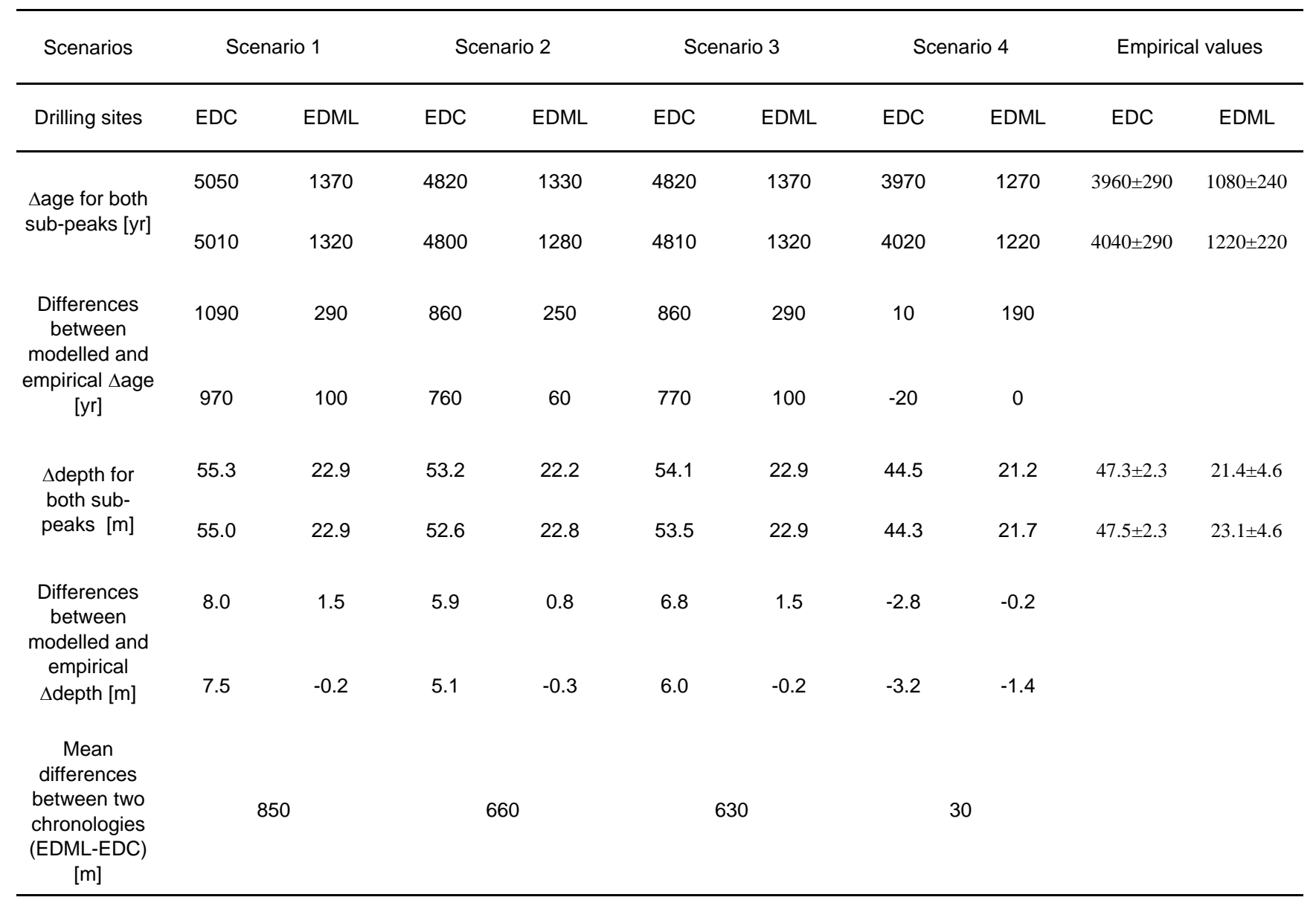

4.2 Scenario 2: EDC3 and EDML1 accumulation rate histories, reduced amplitude of glacial-interglacial temperature change

In scenario 1 , the modelled $\triangle$ age at both EDML and EDC is too large during the ${ }^{10} \mathrm{Be}$ peak. One way to resolve this discrepancy is to reduce the amplitude of the glacial-interglacial temperature change. Relatively warmer temperatures lead to a faster densification process, a shallower close-off depth and a reduced $\triangle$ age. In scenario 2 we keep the EDC3 and EDML1 accumulation rates unchanged (Sect. 3.1) and we reduce the glacial-interglacial temperature amplitude to a factor $\alpha=0.1403 \mathrm{~K} / \%$.

This scenario generally gives a slightly better agreement than scenario 1 with the empirical constraints derived in Sect. 3 (Table 3 and Fig. 4). The difference between the EDC and EDML gas age scales is slightly reduced, with an average of $660 \mathrm{yr}$. During the ${ }^{10} \mathrm{Be}$ sub-peaks $\triangle$ age at EDC (EDML) is $4820 \mathrm{yr}$ and $4800 \mathrm{yr}(1330$ and $1280 \mathrm{yr}$ ), around $20 \%(10 \%)$ higher than the empirical values. $\Delta$ depth at EDC $(53.2$ and $52.6 \mathrm{~m})$ remains significantly larger than the empir- ical values. For EDML, the $\Delta$ depth $(22.2$ and $22.8 \mathrm{~m})$ is still a little bit larger than the empirical values.

4.3 Scenario 3: EDC3 and EDML1 accumulation rate histories, EDC temperature corrected for source effects

In this scenario, the EDC3 temperature history is corrected for variations in the mean ocean isotopic composition, but not for source temperature variations. Vimeux et al. (2002) showed for the Vostok ice core that taking into account source temperature variations reduces the amplitude of the glacial-interglacial surface temperature change by up to $2^{\circ} \mathrm{C}$. In scenario 3 , we apply such a correction using the deuterium excess record (Stenni et al., 2003, and new data, B. Stenni, personal communication). In general, temperatures are warmer during the glacial period compared to scenario 1. The EDC accumulation rate history is kept identical to scenario 1, as well as the EDML temperature and accumulation rate histories.

Overall, this scenario gives results very close to scenario 2 (Table 3 and Fig. 4). The agreement between the EDC and 
EDML gas age scales is slightly improved, with an average shift of $630 \mathrm{yr}$. During the ${ }^{10} \mathrm{Be}$ sub-peaks, the EDC $\triangle$ age is $4820 \mathrm{yr}$ and $4810 \mathrm{yr}$, around $20 \%$ higher than the empirical values. The EDC $\Delta$ depth $(54.1 \mathrm{~m}$ and $53.5 \mathrm{~m})$ remains significantly larger than the empirical values. For EDML, this scenario 3 is the same as scenario 1 .

4.4 Scenario 4: EDC3 and EDML1 temperature histories, reduced amplitude of glacial-interglacial accumulation rate changes

Another way to reduce $\Delta$ age is to increase the past accumulation rate. In scenario 4 , we choose $\beta$ to be 0.0094 for EDC and 0.0120 for EDML, the temperature histories remaining identical to scenario 1 . These values have been obtained by a manual trial and error method, in order to minimize the discrepancy between model and empirical constraints.

Overall this scenario provides an excellent agreement with the EDC-EDML empirical constraint, with an average shift of only $30 \mathrm{yr}$ (Table 3, Figs. 4, 5a). There are two notable exceptions: during the last deglaciation, the EDML gas chronology is older than the EDC one by a few centuries, and vice versa during $\mathrm{DO} \# 9$.

During the ${ }^{10} \mathrm{Be}$ sub-peaks, EDC (EDML) $\Delta$ age is $3970 \mathrm{yr}$ and $4020 \mathrm{yr}$ (1270 and $1220 \mathrm{yr})$, in excellent agreement with the empirical values and well within their confidence intervals.

$\Delta$ depth at EDC (44.5 m and $44.3 \mathrm{~m})$ and EDML (21.7 m and $21.7 \mathrm{~m}$ ) are now significantly smaller, and also in good agreement with the empirical values. Indeed, $\Delta$ depth is equal to the product of the close-off depth in ice equivalent (CODIE) times the thinning function. In this scenario, we increased the glacial accumulation rate while keeping the same ice chronology, and thus implicitly decreased this thinning function, thus leading to smaller $\Delta$ depths.

In Fig. 5b, the EPICA gas chronologies are compared to the NorthGRIP one. The Antarctic ice age time scales were fitted to NorthGRIP time scale at the ${ }^{10} \mathrm{Be}$ peak (Parrenin et al., 2007). Disagreements between the GICC05 and the EDC or EDML gas age time scale away from the ${ }^{10} \mathrm{Be}$ peak thus may result either from an error in the Antarctica-Greenland ice synchronisation, or/and from an error in the $\Delta$ age estimates at the Antarctic sites. As expected, EDC and NorthGRIP chronologies agree well at the time of DO \#8 (EDC gas trapped at the depth of the ${ }^{10} \mathrm{Be}$ peak), i.e. at the depth of the 10Be-peak empirical constraint.

\section{Discussion}

The comparison between our empirical constraints on EDC and EDML $\Delta$ age and $\Delta$ depth and different firn densification modelling scenarios indicate that the official EDC3 and EDML1 ice chronology, temperature and accumulation rate histories are clearly inconsistent with the EDML-EDC

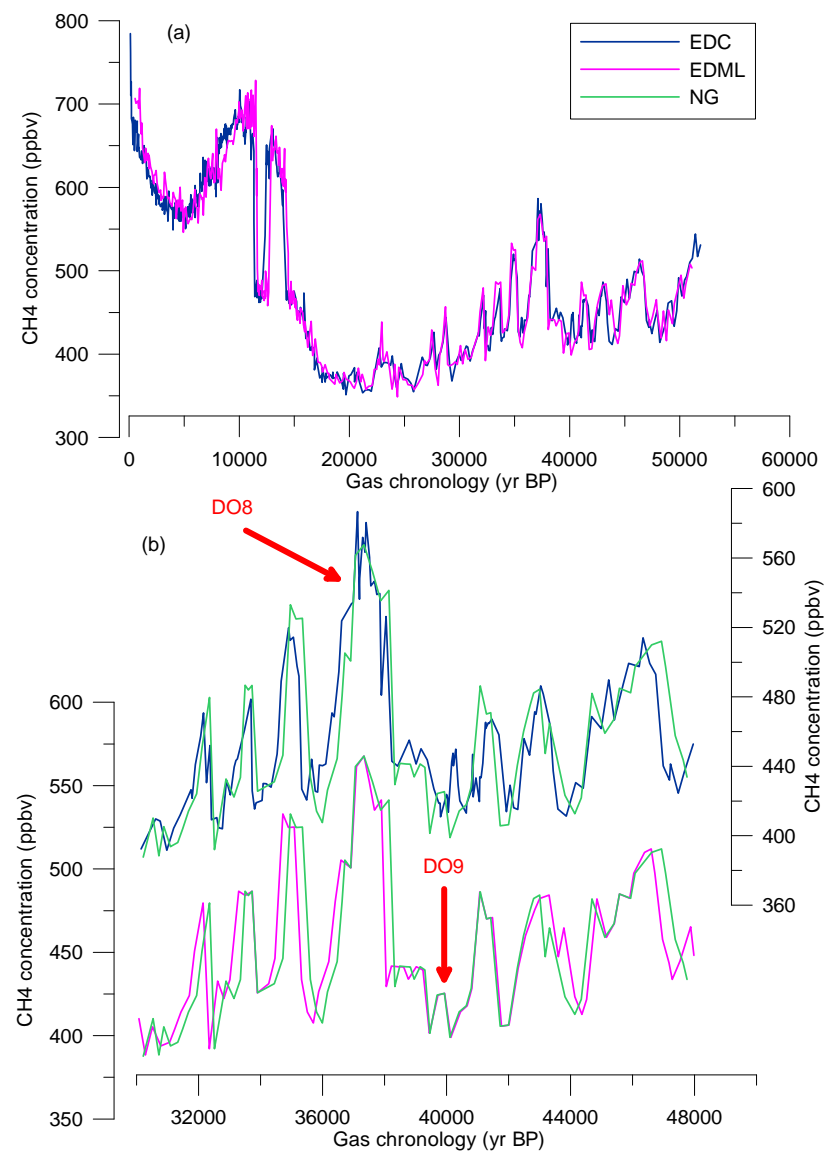

Fig. 5. Comparison between EDC methane (blue curve), EDML methane (pink curve) and NorthGRIP isotope (green curve). NorthGRIP age scale is GICC05. EDC and EDML gas age scales are from scenario 4 (see Sect. 4.4).

methane synchronization constraint. Either the EDC glacial $\Delta$ age is greatly overestimated or the EDML glacial $\Delta$ age is greatly underestimated. Such an inconsistency of EDC modelled gas ages has already been suggested by comparing them to the Byrd ice core constraints (Schwander et al., 2001). The shift between the two gas chronologies roughly resembles the isotopic signal (being inversely correlated, Fig. 4).

Comparison between model and empirical $\Delta$ age constraints based on methane synchronization was also done for the Vostok (low accumulation rate) and Byrd ice cores (high accumulation rate) (Blunier et al., 2004; Bender et al. 2006). Results are not unambiguous; and systematic overestimation of $\Delta$ age by the model has not been considered. At Vostok, the thinning of ice is related to the thickness of the ice column upstream from the drilling site, where the ice originates from. As shown by Parrenin et al. (2004), differences of up to $20 \%$ in the thinning function at Vostok can be obtained depending on the scenario on the ice flow. This makes Vostok a less suitable site than EDC to constraint $\Delta$ age and $\Delta$ depth based on the ice and gas chronological tie points. At EDC, if the 
dome location remained stable, the total thinning is approximately linearly related to the depth of ice layers (Parrenin et al., 2007).

The origin of the inconsistency between model outputs and the observation lies 1) either in the parameterization of the surface temperature; or 2) in the parametrization of the surface accumulation rate; or 3 ) in the calculation of the thinning function at both sites; or 4) in the physical representation of the densification process in the model; or 5) any combination of the four previous options.

A test with different temperature scenarios (scenarios 2 and 3) only removes a fraction of the disagreement with empirical constraints. These scenarios reduce the glacialinterglacial amplitude of temperature change by about $15 \%$, which seems to be a maximum bound according to different evidences presently available for the East Antarctic plateau (Jouzel et al., 2003; Blunier et al., 2004). Salamatin et al. (1998) and Tsyganova and Salamatin (2004) suggest on the other hand a large underestimate of the temperature change, which would make even worse the disagreement between modelled and observed $\Delta$ age and $\Delta$ depth. To our knowledge, there is no other study proposing smaller amplitude of glacial-interglacial temperature change than the one deduced from the standard isotope/temperature relationship in Antarctica. In summary, only a small fraction of the disagreement can thus originate from the temperature scenario.

Using larger glacial accumulation rates at both EDC and EMDL (scenario 4) than those classically deduced from water isotopes, we are able to get a much improved agreement between firn densification model outputs and $\Delta$ age empirical constraints. But at EDC, it represents an average accumulation rate of $63 \%$ of the present-day value during the last glacial maximum, corresponding to an increase of more than $30 \%$ with respect to the EDC3 official scenario. The annual layer thickness in the EDC3 chronology is the product of the accumulation rate (the initial annual layer thickness) and the thinning function (evaluated with a mechanical ice-flow model, Parrenin et al., 2007). The EDC3 chronology is constrained within $\sim 1 \mathrm{kyr}$ at the location of the ${ }^{10} \mathrm{Be}$ peak 41 kyr BP, being synchronized onto the NorthGRIP annual layer-counted GICC05 age scale (Andersen et al., 2006; Svensson et al., 2006). Increased glacial accumulation rates as in scenario 4 are thus physically compatible with the ice core chronology only if they are compensated by a proportional decrease in the thinning function. However, the latter varies between 1 at the surface and 0.75 at $850 \mathrm{~m}$ of depth $(\sim 50 \mathrm{kyr} \mathrm{BP})$ and it is considered very well constrained under ice-flow conditions for the upper quarter of an ice dome (Parrenin et al., 2007). A correction of about $30 \%$ of the thinning function in this EDC depth range thus seems to be unrealistic.

It could be argued that the EDML-EDC methane disagreement results from an underestimated $\triangle$ age at EDML. However, EDML $\triangle$ age during the last glacial amounts to 1000 $1500 \mathrm{yr}$, and a mean underestimate of $800 \mathrm{yr}$ (50 to $80 \%$ ) is not feasible. We conclude that the firn densification model overestimates $\triangle$ age at EDC during the last glacial period.

A possible origin of disagreement between model and empirical constraints is a missing phenomenon in the firn densification model. As already suggested by the $\delta^{15} \mathrm{~N}$ data at Vostok (Sowers et al., 1992), firn densification models could lead to an overestimate of the close-off depth for the very cold and low accumulation conditions of the glacial Antarctic plateau, for which no present-day analogue exists so far. There are 3 possible sources of modelling errors. First, surface density may be underestimated during glacial times. Indeed, surface density depends on the characteristics of the surface: megadunes, glazed surfaces and areas with relative densities of $\sim 0.5$ have been observed on the East Antarctic plateau and make this option plausible. Second, the densification velocity may be underestimated for glacial conditions. The densification model of Salamatin et al. (2007), simultaneously calculating grain sliding and plastic deformation along the firn column, indeed leads to faster densification that the model of Goujon et al. (2003). Third, the density at the close-off depth may be less during glacial times. The density at the bottom of the non-diffusive zone is relatively well constrained by the total air content measurements, and we thus do not expect important changes. But the depth difference between the Lock-In Depth (where gases stop diffusing) and the COD (where gases are on average definitely trapped) may be significantly larger than today for glacial conditions. At this stage, we have no strong argument to favour any of these options.

What is not satisfying in any of the scenarios above is that the modelled COD is much too large compared to the observed LID calculated from $\delta^{15} \mathrm{~N}$ data for EDML (Landais et al., 2006). We made the following experiment in attempt to bring both $\triangle$ age and COD in agreement with the observation. We reduced COD from scenario 1 (with a largely overestimated $\Delta$ age) by a given factor so that it is in better agreement to the $\delta^{15} \mathrm{~N}$ derived LID during the glacial (data not shown here). By this totally empirical correction it is possible to get a generally good agreement with the empirical values, about similar to scenario 4 with respect to $\Delta$ age. However, the limitation of this approach is that the physics in this process is not explained and that the variations of $\delta^{15} \mathrm{~N}$ parameter is not fully understood for glacial conditions for a lot of different sites (EDML; Landais et al., 2006, EDC, Berkner; Capron et al., 2007).

Whatever the physical explanation, our re-evaluation of $\triangle$ age at EDC has potentially large consequences on one of the key questions regarding climate and carbon cycle dynamics: the relative timing between Antarctic climate and $\mathrm{CO}_{2}$ mixing ratio changes. Current estimates of the time relationship between the two signals at the start of the last deglaciation based on detailed EDC measurements, point to a $\mathrm{CO}_{2}$ lag of $800 \pm 600 \mathrm{yr}$ compared to the $\delta \mathrm{D}$ increase (Monnin et al., 2001). This conclusion based on a $\Delta$ age calculation similar to scenario 1 has to be revisited, as this scenario applied 
to the ${ }^{10} \mathrm{Be}$ peak at $41.2 \mathrm{kyr} \mathrm{BP}$ leads to a $\triangle$ age overestimate of more than $1000 \mathrm{yr}$. Indeed the gas age difference between EDC and EDML shows an overestimate for the entire glacial period and the last deglaciation. We conclude that the $\mathrm{CO}_{2}$ deglacial increase took place with a significantly smaller lag over Antarctic temperature than previously suggested. The consequences of such a suggestion are far beyond the scope of this paper and should certainly wait for confirmation through other time markers in the ice allowing a direct chronological fit between EDC and the Greenland ice. Furthermore $\mathrm{CO}_{2}$ measurements on the EDML core with a much smaller $\Delta$ age will allow estimation of the timing of $\mathrm{CO}_{2}$ and temperature rise with much more confidence. However, with the information at hand through our study, it is likely that the EDC $\triangle$ age and therefore the $\mathrm{CO}_{2}$ lag on East Antarctic temperature has also been overestimated around 18 kyr BP.

\section{Conclusions}

An improved time resolution of $\mathrm{CH}_{4}$ measurements on the EDC and EDML ice cores, notably over DO \#9 and 10, allowed us to evaluate the compatibility of the EDC and EDML gas chronologies. The combination of EDC-EDML gas synchronisation through $\mathrm{CH}_{4}$ and ice synchronisation through volcanic horizons provides a constraint on the gas age-ice age difference at both sites. At the location of the $41 \mathrm{kyr}$ ${ }^{10} \mathrm{Be}$ event, the ice synchronisation of EDC with NorthGRIP allows us to empirically evaluate this $\Delta$ age (as well as the $\Delta$ depth) for EDC and EDML.

The EDC $\Delta$ age and $\Delta$ depth produced by the firn densification model can match our new empirical constraints only through larger accumulation rate at EDC and EDML during the last glacial period, compared with current estimates. However, it requires modification of the EDC chronology, which would change either the age of the $41 \mathrm{kyr}{ }^{10} \mathrm{Be}$ event, or the modelled EDC thinning function, both of them being robust estimates. Although the exact causes of the $\Delta$ age overestimate remain unknown, our work implies that the suggested lag of $\mathrm{CO}_{2}$ on Antarctic temperature at the start of the last deglaciation has probably been overestimated.

Independent estimates of paleo-accumulation rates via chemical tracers would remove the current doubt on the accumulation rate scenario. In addition, the precision of our method could be improved through direct synchronisation of a future detailed $\mathrm{CH}_{4}$ record from NorthGRIP with its Antarctic counterparts. Finally, a similar study of the Japanese Dome Fuji ice core, also situated on a dome and characterized by a slightly larger accumulation rate relative to EDC, would help to better understand the physics behind the densification process on the East Antarctic plateau during glacial conditions.

Acknowledgements. This work is a contribution to the European Project for Ice Coring in Antarctica (EPICA), a joint European
Science Foundation/European Commission scientific programme, funded by the EU (EPICA-MIS) and by national contributions from Belgium, Denmark, France, Germany, Italy, the Netherlands, Norway, Sweden, Switzerland and the United Kingdom. The main logistic support was provided by IPEV and PNRA (at Dome C) and AWI (at Dronning Maud Land). This is EPICA publication no. 182.

Edited by: E. W. Wolff

\section{References}

Ahn, J., Wahlen, M., Deck, B. L., Brook, E. J., Mayewski, P. A., Taylor, K. C., and White, J. W. C.: A record of atmospheric CO2 during the last 40000 years from the Siple Dome, Antarctica ice core, J. Geophys. Res., 109, 13 305, doi:10.1029/2003JD004415, 2004.

Andersen, K. K., Svensson, A., Johnsen, S. J., Rasmussen, S. O., Bigler, M., Röthlisberger, R., Ruth, U., Siggaard-Andersen, M.-L., Steffensen, J. P., Dahl-Jensen, D., Vinther, B. M., and Clausen, H. B.: The Greenland Ice Core Chronology 2005, 1542 ka. Part 1: constructing the time scale, Quat. Sci. Rev., 25, 3246-3257, 2006.

Anklin, M., Barnola, J.-M., Schwander, J., Stauffer, B., and Raynaud, D.: Processes affecting the $\mathrm{CO} 2$ concentration measured in Greenland ice, Tellus Ser., B(47), 461-470, 1995.

Arnaud, L., Barnola, J.-M., and Duval, P.: Physical modeling of the densification of snow/firn and ice in the upper part of polar ice sheets. Physics of Ice Core Records, T. Hondoh, Sapporo, Hokkaido University Press, 285-305, 2000.

Barnola, J.-M., Pimienta, P., Raynaud, D., and Korotkevich, Y. S.: CO2-climate relationship as deduced from the Vostok ice core: a re-examination based on new measurements and on a re-evaluation of the air dating, Tellus, 43 B, 83-90, 1991.

Bender, M. L., Floch, G., Chappellaz, J., Suwa, M., Barnola, J.-M., Blunier, T., Dreyfus, G., Jouzel, J., and Parrenin, F.: Gas age-ice age differences and the chronology of the Vostok ice core, 0-100 ka, J. Geophys. Res., 111, D21115, doi:10.1029/2005JD006488, 2006.

Bender, M. L., Sowers, T., Dickson, M.-L., Orchardo, J., Grootes, P., Mayewski, P. A., and Meese, D. A.: Climate correlations between Greenland and Antarctica during the past 100000 years, Nature, 372, 663-666. 1994.

Bintanja, R., Van De Wal, R. S. W., and Oerlemans, J.: Modelled atmospheric temperatures and global sea levels over the past million years, Nature, 437, 125-128, 2005.

Blunier, T., Spahni, R., Barnola, J. M., Loulergue, L., and Schwander, J.: Synchronization of ice core records via atmospheric gases, Clim. Past, 3, 325-330, 2007, http://www.clim-past.net/3/325/2007/.

Blunier, T., Schwander, J., Chappellaz, J., Parrenin, F., and Barnola, J.-M.: What was the surface temperature in central Antarctica during the last glacial maximum?, Earth Planet. Sci. Lett., 218, 379-388, 2004.

Blunier, T. and Brook, E. J.: Timing of Millennial-Scale climate change in Antarctica and Greenland during the last glacial period, Science, 291, 109-111, 2001.

Blunier, T., Chappellaz, J., Schwander, J., Dällenbach, A., Stauffer, B., Stocker, T. F., Raynaud, D., Jouzel, J., Clausens, H. B., Hammer, C. U., and Johnsen, S. J.: Asynchrony of Antarctic and 
Greenland climate change during the last glacial period, Nature, 394, 739-743, 1998.

Blunier, T., Schwander, J., Stauffer, B., Stocker, T. F., Dallenbach, A., Indermühle, A., and Tschumi, J.: Timing of the Antarctic Cold Reversal and the atmospheric $\mathrm{CO} 2$ increase with respect to the Younger Dryas event, Geophys. Res. Lett., 24, 2683-2686, 1997.

Caillon, N., Severinghaus, J. P., Jouzel, J., Barnola, J.-M., Kang, J., and Lipenkov, V. Y.: Timing of atmospheric CO2 and Antarctic temperature changes across termination III, Science, 299, 17281731, 2003.

Caillon, N., Severinghaus, J. P., Barnola, J.-M., Chappellaz, J., Jouzel, J., and Parrenin, F.: Estimation of temperature change and of gas age-ice age difference, 108 kyr B.P., at Vostok, Antarctica, J. Geophys. Res., 106(D23), 31 893-31 901, 2001.

Capron, E.: Mémoire de Master 2, Interaction Climat Environnement (UVSQ), Analyse de la composition isotopique de l'air piégé dans la glace de Berkner Island (Antarctique de l'Ouest) pendant la dernière déglaciation, p.30, 2007.

Chappellaz, J., Blunier, T., Kints, S., Dällenbach, A., Barnola, J.M., Schwander, J., Raynaud, D., and Stauffer, B.: Changes in the atmospheric $\mathrm{CH} 4$ gradient between Greenland and Antarctica during the Holocene, J. Geophys. Res., 102(D13), $15987-$ $15997,1997$.

Chappellaz, J., Blunier, T., Raynaud, D., Barnola, J.-M., Schwander, J., and Stauffer, B.: Synchronous changes in atmospheric $\mathrm{CH} 4$ and Greenland climate between 40 and $8 \mathrm{kyr}$ BP, Nature, 366, 443-445, 1993.

Eisen, O., Rack, W., Nixdorf, U., and Whilhelms, F.: Characteristics of accumulation around the EPICA deep-drilling site in Dronning Maud Land, Antarctica, Ann. Glaciol., 41, 41-46, 2005.

Epica, C. M.: One-to-one interhemispheric coupling of polar climate variability during the last glacial, Nature, 444, 195-198, doi:10.1038/nature05301, 2006.

Fischer, H., Wahlen, M., Smith, J., Mastroianni, D., and Deck, B. $\mathrm{L}$.: Ice core records of atmospheric $\mathrm{CO} 2$ around the last three glacial terminations, Science, 283, 1712-1714, 1999.

Flückiger, J., Blunier, T., Stauffer, B., Chappellaz, J., Spahni, R., Kawamura, K., Schwander, J., Stocker, T. F., and Dahl-Jensen, D.: $\mathrm{N} 20$ and $\mathrm{CH} 4$ variations during the last glacial epoch: insight into global processes, Global Biogeochem. Cy., 16, $227-$ 230, 2002.

Flückiger, J., Dällenbach, A., Blunier, T., Stauffer, B., Stocker, T. F., Raynaud, D., and Barnola, J.-M.: Variations in atmospheric $\mathrm{N} 2 \mathrm{O}$ concentration during abrupt climatic changes, Science, 285, 227-230, 1999.

Goujon, C., Barnola, J.-M., and Ritz, C.: Modeling the densification of polar firn including heat diffusion: Application to close-off characteristics and gas isotopic fractionation for Antarctica and Greenland sites, J. Geophys. Res., 108, 4792, doi:10.1029/2002JD003319, 2003.

Guillou, H., Singer, B. S., Laj, C., Kissel, C., Scaillet, S., and Jicha, B. R.: On the age of the Laschamp geomagnetic excursion, Earth Planet. Sci. Lett., 227, 331-343, 2004.

Herron, M. M. and Langway, C. C.: Firn densification: an empirical model, J. Glaciol., 25, 373-385, 1980.

Jouzel, J., Masson-Delmotte, V., Cattani, O., Dreyfus, G., Falourd, S., Gallet, J.-C., Hoffmann, G., Nouet, J., Barnola, J.-M., Chap- pellaz, J., Fischer, H., Johnsen, S. J., Leuenberger, M., Loulergue, L., Luethi, D., Oerter, H., Parrenin, F., Raisbeck, G. M., Raynaud, D., Schwander, J., Spahni, R., Souchez, R., Selmo, E., Schilt, A., Steffensen, J. P., Stenni, B., Stauffer, B., Stocker, T. F., Tison, J.-L., Werner, M., and Wolff, E.: Orbital and millenial antarctic climate variability over the last 800000 years, Science, 317, 793-796, 2007.

Jouzel, J., Vimeux, F., Caillon, N., Delaygue, G., Hoffmann, G., Masson-Delmotte, V., and Parrenin, F.: Magnitude of isotope/temperature scaling for interpretation of central Antarctic ice cores, J.Geophys. Res., 108(D12), 4361, doi:10.1029/2002JD002677, 2003.

Jouzel, J., Alley, R. B., Cuffey, K. M., Dansgaard, W., Grootes, P., Hoffmann, G., Johnsen, S. J., Koster, R. D., Peel, D., Shuman, C. A., Stievenard, M., Stuiver, M., and White, J.: Validity of the temperature reconstruction from water isotopes in ice cores, J. Geophys. Res., 102(C12), 26471-26487, 1997.

Landais, A., Barnola, J.-M., Kawamura, K., Caillon, N., Delmotte, M., Van Ommen, T. D., Dreyfus, G., Jouzel, J., MassonDelmotte, V., Minster, B., Freitag, J., Leuenberger, M., Schwander, J., Huber, C., Etheridge, D. M., and Morgan, V.: Firn-air $\mathrm{d} 15 \mathrm{~N}$ in modern polar sites and glacial-interglacial ice: a modeldata mismatch during glacial periods in Antarctica?, Quat. Sci Rev., 25, 49-62, 2006.

Landais A., Caillon, N., Goujon, C., Grachev, A. M., Barnola, J.M., Chappellaz, J., Jouzel, J., Masson-Delmotte, V., and Leuenberger, M.: Quantification of rapid temperature change during DO event 12 and phasing with methane inferred from air isotopic measurements, Earth Planet. Sci. Lett., 225, 221-232, 2004.

Lorius, C. and Merlivat, L.: Distribution of mean surface stable isotope values in east Antarctica. Observed changes with depth in a coastal area, in: Isotopes and impurities in snow and ice, Proceedings of the grenoble symposium, August/September 1975, volume 118 of IAHS, Publication, IAHS, Vienna, 1977.

Mazaud, A., Laj, C., and Bender, M. L.: A geomagnetic chronology for antarctic ice accumulation, Geophys. Res. Lett., 21(5), 337340, 1994.

Monnin, E., Indermühle, A., Dällenbach, A., Flückiger, J., Stauffer, B., Stocker, T. F., Raynaud, D., and Barnola, J.-M.: Atmospheric $\mathrm{CO} 2$ concentrations over the last glacial termination, Science, 291, 112-114, 2001.

Neftel, A., Oeschger, H., Staffelbach, T., and Stauffer, B.: CO2 record in the Byrd ice core 50 000-5000 years BP, Nature, 331, 609-611, 1988.

North Greenland, Community Members: High resolution record of Northern Hemisphere climate extending into the last interglacial period, Nature, 2805, 1-5, 2004.

Parrenin, F., Dreyfus, G., Durand, G., Fujita, S., Gagliardini, O., Gillet, F., Jouzel, J., Kawamura, K., Lhomme, N., MassonDelmotte, V., Ritz, C., Schwander, J., Shoji, H., Uemura, R., Watanabe, M., Wolff, E., and Yoshida, N.: Ice flow modelling at EPICA Dome C and Dome Fuji, East Antarctica, Clim. Past Discuss., 3, 19-61, 2007, http://www.clim-past-discuss.net/3/19/2007/.

Parrenin, F., Barnola, J.-M., Beer, J., Blunier, T., Castellano, E., Chappellaz, J., Dreyfus, G., Fischer, H., Fujita, S., Jouzel, J., Kawamura, K., Lemieux, B., Loulergue, L., Masson-Delmotte, V., Narcisi, B., Petit, J.-R., Raisbeck, G. M., Raynaud, D., Ruth, U., Schwander, J., Severi, M., Spahni, R., Steffensen, J. P., 
Svensson, A., Udisti, R., Waelbroeck, C., and Wolff, E.: The EDC3 agescale for the EPICA Dome $\mathrm{C}$ ice core, Clim. Past Discuss., 3, 575-606, 2007a.

Parrenin, F., Remy, F., Ritz, C., Siegert, M. J., and Jouzel, J.: New modeling of the Vostok ice flow line and implication for the glaciological chronology of the Vostok ice core, J. Geophys. Res., 109, D20102, doi:10.1029/2004JD004561, 2004.

Parrenin, F., Jouzel, J., Waelbroek, C., Ritz, C., and Barnola, J.-M.: Dating the Vostok ice core by an inverse method, J. Geophys. Res., 106(D23), 31 837-31 851, 2001.

Pimienta, P.: Etude du comportement mécanique des glaces polycristallines aux faibles contraintes; applications aux glaces des calottes polaires, Grenoble, Université Joseph Fourier, 1987.

Raisbeck, G. M., Yiou, F., Jouzel, J., and Stocker, T. F.: Direct North-South Synchronization of abrupt climate change records in ice cores using ${ }^{10} \mathrm{Be}$, Clim. Past Discuss., 3, 755-769, 2007, http://www.clim-past-discuss.net/3/755/2007/.

Raisbeck, G. M., Yiou, F., and Jouzel, J.: Cosmogenic 10Be as a high-resolution correlation tool for climate records, Geochimica and cosmochimica acta Acta, 66, A623, 2002.

Rasmussen, S. O., Seierstad, I. K., Andersen, K. K., Bigler, M., Dahl-Jensen, D., Jonhsen, S. J.: Synchronization of the NGRIP, GRIP, and GISP2 ice cores across MIS 2 and palaeoclimatic implications. Quat. Sci. Rev, INTIMATE special issue, accepted, 2007.

Rasmussen, S. O., Andersen, K. K., Svensson, A., Steffensen, J. P., Vinther, M., Clausens, H. B., Siggard-Andersen, M. L., Johnsen, S. J., Larsen, L. B., Bigler, M., Röthlisberger, R., Fisher, H., Goto-Azuma, K., Hansson, M., and Ruth, U.: A new Greenland ice core chronology for the last glacial termination, J. Geophys. Res., 111, D06102, doi:10.1029/2005JD006079, 2006.

Ruth, U., Barnola, J.-M., Beer, J., Bigler, M., Blunier, T., Castellano, E., Fischer, H., Fundel, F., Huybrechts, P., Kaufmann, P., Kipfstuhl, J., Lambrecht, A., Morganti, A., Oerter, H., Parrenin, F., Rybak, O., Severi, M., Udisti, R., Wilhelms, F., and Wolff, E.: EDML1: A chronology for the EDML ice core, Antarctica, over the last 150000 years, Clim. Past, 3, 475-484, 2007, http://www.clim-past.net/3/475/2007/.

Salamatin, A. N., Lipenkov, V. Y., Barnola, J.-M., Hori, J. M., Duval, P., and Hondoh, T.: Basic approaches to dry snow-firn densification modelling, Materialy Glyatsiologicheskih Issledovaniy, 101, in press, 2007.

Salamatin, A. N., Lipenkov, V. Y., Barkov, N. I., Jouzel, J., Petit, J.R., and Raynaud, D.: Ice core age dating and paleothermometer calibration based on isotope and temperature profiles from deep boreholes at Vostok station (east Antarctica), J. Geophys. Res., 103(D8), 8963-8977, 1998.

Schwander, J., Jouzel, J., Hammer, C. U., Petit, J.-R., Udisti, R., and Wolff, E.: A tentative chronology for the EPICA Dome Concordia ice core, Geophys. Res. Lett., 28(22), 4243-4246, 2001.

Schwander, J., Sowers, T., Barnola, J.-M., Blunier, T., Fuchs, A., and Malaizé, B.: Age scale of the air in the summit ice: Implication for glacial-interglacial temperature change, J. Geophys. Res., 102(D16), 19483-19493, 1997.

Severi, M., Castellano, E., Morganti, A., Udisti, R., Ruth, U., Fischer, H., Huybrechts, P., Wolff, E., Parrenin, F., Kaufmann, P., Lambert, F., and Steffensen, J. P.: Synchronisation of the EDML1 and EDC3 timescales for the last $52 \mathrm{kyr}$ by volcanic signatures matching, Clim. Past Discuss., 3, 409-433, 2007, http://www.clim-past-discuss.net/3/409/2007/.

Severinghaus, J. P. and Brook, E. J.: Abrupt climate change at the end of the last glacial period inferred from trapped air in polar ice, Science, 286, 930-933, 1999.

Severinghaus, J. P., Sowers, T., Brook, E. J., Alley, R. B., and Bender, M. L.: Timing of abrupt climate change at the end of the Younger Dryas interval from thermally fractionated gases in polar ice, Nature, 391, 141-144, 1998.

Siegenthaler, U., Stocker, T. F., Monnin, E., Lüthi, D., Schwander, J., Stauffer, B., Raynaud, D., Barnola, J.-M., Fischer, H., Masson-Delmotte, V., and Jouzel, J.: Stable carbon cycle-climate relationship during the late pleistocene, Science, 310, 1313$1317,2005$.

Sowers, T.: N2O record spanning the penultimate deglaciation from the Vostok ice core, J. Geophys. Res., 106(D23), 31 903-31 914, 2001.

Sowers, T., Bender, M. L., Labeyrie, L., Martinson, D., Jouzel, J., Raynaud, D., Pichon, J. J., and Korotkevich, Y. S.: A 135000 year Vostok-SPECMAP common temporal framework, Paleoceanography, 8(6), 737-766, 1993.

Sowers, T., Bender, M., Raynaud, D., and Korotkevich, Y. L.: The $\delta^{15} \mathrm{~N}$ of $\mathrm{O} 2$ in air trapped in polar ice: a tracer of gas transport in the firn and a possible constraint on ice age-gas age differences, J. Geophys. Res., 97, 15, 15 683-15 697, 1992.

Spahni, R., Chappellaz, J., Stocker, T. F., Loulergue, L., Hausammann, G., Kawamura, K., Flückiger, J., Schwander, J., Raynaud, D., Masson-Delmotte, V., and Jouzel, J.: Variations of atmospheric methane and nitrous oxide during the last 650000 years from Antarctic ice cores, Science, 310, 1317-1321, 2005.

Stauffer, B., Flückiger, J., Monnin, E., Nakazawa, T., and Aoki, S.: Discussion of the reliability of $\mathrm{CO} 2, \mathrm{CH} 4$ and $\mathrm{N} 2 \mathrm{O}$ records from polar ice cores, Memoirs of National Institute of Polar Research, Special Issue (Japan), Global Scale Climate and Environment Study trough Polar Deep Ice Cores, 57, 139-152, 2003.

Steig, E. J. and Alley, R. B.: Phase relationship between Antarctic and Greenland climate records, Ann. Glaciol., 35, 451-456, 2002.

Stenni, B., Jouzel, J., Masson-Delmotte, V., Röthlisberger, R., Castellano, E., Cattani, O., Falourd, S., Johnsen, S. J., Longinelli, A., Sachs, J. P., Selmo, E., Souchez, R., Steffensen, J. P., and Udisti, R.: A late-glacial high resolution site and source temperature record derived from the EPICA Dome C isotope records (East Antarctica), Earth Planet. Sci. Lett., 217, 183-195, 2003.

Stocker, T. F. and Johnsen, S. J.: A minimum thermodynamic model for the bipolar seesaw, Paleoceanography, 18, 1087, doi:10.1029/2003PA000920, 2003.

Svensson, A., Andersen, K. K., Bigler, M., Clausen, H. B., DahlJensen, D., Davies, S., M., Johnsen, S. J., Muscheler, R., Rasmussen, S. O., Röthlisberger, R., Steffensen, J. P., and Vinther, B. M.: The Greenland Ice Core Chronology 2005: 15-42 ka. Part 2: comparison to others records, Quat. Sci. Rev., 25, 3258-3267, 2007.

Tsyganova, E. A. and Salamatin, A. N.: Non-stationary temperature field simulations along the ice flow line "Ridge B - Vostok Station”, East Antarctica, Materialy Glyatsiologicheskih Issledovaniy, Data of Glaciological Studies, 97, 57-70, 2004.

Van Ommen, T. D., Morgan, V., and Curran, M.: Deglacial and Holocene changes in accumulation at Law Dome, East Antarctica, Ann. Glaciol., 39(1), 359-365, 2004. 
Vimeux, F., Cuffey, K. M., and Jouzel, J.: New insights into Southern Hemisphere temperature changes from Vostok ice cores using deuterium excess correction, Earth Planet. Sci. Lett., 203, 829-843, 2002.

Vinther, M., Clausens, H. B., Johnsen, S. J., Rasmussen, S. O., Andersen, K. K., Buchardt, S. L., Dahl-Jensen, D., Seierstad, I. K., Siggard-Andersen, M. L., Steffensen, J. P., Svensson, A., Olsen, J., and Heinemeier, J.: A synchronized dating of three Greenland ice cores throughout the Holocene, Geophys. Res. Lett., 111, D13102, doi:10.1029/2005JD006921, 2006.
Yiou, F., Raisbeck, G. M., Baumgartner, S., Beer, J., Hammer, C., Johnsen, S. J., Jouzel, J., Kubik, P. W., Lestringuez, J., Stievenard, M., Suter, M., and Yiou, P.: Beryllium 10 in the Greenland Ice Core Project ice core at Summit, Greenland, J. Geophys. Res., 102(C12), 26 783-26794, 1997. 